\title{
Wind Resource Assessment using Ramp Detection Technique
}

\author{
Monika Agrawal, Arun Kumar Nayak \\ Department of Electrical Engineering, Swami Keshvanand Institute of Technology, Management and \\ Gramothan, Jaipur-302017 (INDIA) \\ Email-monicaagrawal051@gmail.com \\ Received 08.08.2019 received in revised form 12.10.2020, accepted 12.10.2020
}

\begin{abstract}
Due to rising load demand throughout the world and depleting nature of existing fossil fuels, the penetration of renewable energy sources (RES) to the grid is increasing. However, the uncertain nature of RESs makes it difficult to directly integrate with the existing conventional power plants. Therefore, it is quite important to consider the intermittent nature of RESs in the formulation and solution procedure. Out of the different RESs, the wind energy is taken into account in this paper and the uncertain nature of wind power is modeled using the ramp detection technique. Ramp events play an important role to fulfill the generationdemand properly. If these ramp events will not controlled, they will produce more pressure on wind turbines and turbine will be destructed. So for protected and steady process, it is essential that executer should have the knowledge about these ramp events. In this paper ramp ups and ramp downs of Dug site in Rajasthan are evaluated for sustainable wind resource assessment. After this, the comparison of these ramp events are done seasonally in which three seasons are taken namely: winter, summer and spring at a particular site for the wind power potential assessment.
\end{abstract}

Keywords -Ramp ups, Ramp downs, Wind power density, Threshold power

\section{INTRODUCTION}

Now a day's wind energy appears as a boon in the field of energy out of all other non-conventional and conventional sources of electric energy. But the main difficulty in the wind power assessment is its stochastic nature and appearance of ramp events in the wind power. As we all know that the requirements of additional sources are increasing day by day because of rise in population and dependence on exhaustible sources of power like coal. So to fulfill the electricity demand, the uncertain nature and ramp events of wind power should be controlled in a limit. Two types of ramp events are there which is ramp ups and ramp downs. These ramp ups and downs affect the working of wind turbine differently. If Ramp ups are there in the wind power then it causes over generation in the output. If the ramp downs are there in the system then loss of generation should be present in output. In case of loss of generation the fulfillment can be done either rising the proportion of other connected lines or by starting backup lines. In case of over generation, improvisation can be done either by reducing the other connected lines or by pushing them off [1]. So if the executer knows about ramp up/down situation, he can manage the power system that time according to the condition of wind power ramps. These ramp events affect the quality of wind power or we can say the overall performance of wind power forecasting system [2]. These ramp events create big difference between actual energy production and generated energy which can be penalized by electricity regulators [3]. For large power producing wind farms, wind power ramps are more challenging as per hour basis [4]. To illustrate the ramp events three parameters are main that is magnitude, direction and duration [5]. According to [6] up ramps are mostly arises in afternoon and down ramps are appears in evening time periods. These ramp events are also harmful for wind turbines and can lead to power rescheduling.So ramp events are the critical issue in wind power generating systems on the basis of voltage drop and cost analysis [7]. In this paper it is described that by evaluating historical on real production from wind farm, we can achieve determinable intuitiveness into the ramp events. This statistical approach of analyzing the historical data can provide us the different answers like: how much ramp events are there, how many times they are repeating, how much harsh the ramps are and do they harm the system or not. In this paper the wind data of Dug site in Rajasthan are collected, to compare the ramp ups/downs for tenable wind power potential assessment.In wind power analysis one benefit is also present there that is the variations in the wind speeds are very similar when compared monthly, yearly and seasonally. That's why if the analysis is done monthly, yearly or seasonally then the possible future outcomes can be predicted.

This paper is arranged as follows: firstly, section 2 shows the description of wind data of proposed site. Following in section 3, the details of problems arises by the ramp events are shown. Section 4 shows the variation of wind power with time. After 
this in the result the seasonal variations of wind ramp ups/downs are shown. At last conclusion is described according to the result that shows which season is more preferable for the proposed study.

\section{DATA DESCRIPTION}

In this study the data of Dug site at Jhalawar in Rajasthan is collected from the National institute of wind energy (NIWE) site [8]. Rajasthan is the northern west side and the largest state of India located between latitude $27.0238^{\circ} \mathrm{N}$ and longitude $74.2179^{\circ} \mathrm{E}$, with elevation ranging from 100 to 350 meter above mean sea level covering geographical area about 3,42,239 square kilometer. The wind data is gathered at 100 meter hub height in 10 minutes interval. The Dug site is geographically placed at the latitude of $23.920^{\circ}$ and longitude of $75.918^{\circ}$. This site is selected according to their high wind power density among the other sites of Rajasthan. Wind speed measuring instrument anemometer is at $100 \mathrm{~m}$ mast height placed at North side. The wind power density at mast height referred as $225.56 \mathrm{watt} / \mathrm{m}^{2}$. For the assessment of wind power, first the data is normalized in time series and then using the cubic relationship of wind speed, wind power is calculated.

\section{PROBLEM FORMULATION}

The main problem in the present study is the ramp ups and downs in the wind power. So in this section the highlights are wind ramps and algorithm.

\subsection{Wind ramps}

Many researchers gave different opinions about the definition of wind ramps in the previous studies. Basically wind ramps are the difference of mean power between two successive hours. Because the wind power is not steady in hourly basis, so these hourly measure of classical events plots can give us an idea of wind ramp operation. These hourly measures can be productive and contradictory [9]. Wind ramp causes massive changes in précised time span. The ratio of difference of sheer power changes between two points to the time interval of those points is termed as the ramp rate. These ramp rates can be higher or upside and lower or downside.

$$
\left|\frac{P_{t 1}-P_{t 2}}{\delta t}\right| \geq P R R_{t h} \text { (i) }
$$

In the above equation [1] $\mathrm{P}_{\mathrm{t} 1}$ and $\mathrm{P}_{\mathrm{t} 2}$ are termed as the powers at time interval $t 1$ and $t 2$ respectively. If the $\mathrm{P}_{\mathrm{t} 2}>\mathrm{P}_{\mathrm{t} 1}$ them the ramp rates are downside and if $\mathrm{P}_{\mathrm{t} 1}>\mathrm{P}_{\mathrm{t} 2}$ then the ramp rates are upside. Upside ramps are called ramp ups and downside ramps are called ramp downs. Here $\mathrm{P}_{\mathrm{t} 1}$ and $\mathrm{P}_{\mathrm{t} 2}$ are powers at different points and $\delta t$ is time interval between two points. $P R R_{t h}$ is the power ramp rate at threshold limit.

\subsection{Wind power density}

Wind power is correlates with the cube of wind speed. If the speed is high the wind power of that particular site is also high.

$$
P=\frac{1}{2} \times \rho \times A \times v^{3} \text { (ii) }
$$

Here $\rho$ is the air densitywhich is approximately fixed i.e. $1.225 \mathrm{~kg} / \mathrm{m}^{2}$. A is the rotor diameter that is kept as $1 \mathrm{~m}^{2}$, v is the wind speed in $\mathrm{m} / \mathrm{sec}$ and $\mathrm{P}$ is the wind power density.

\section{METHODOLOGY}

The proposed methodology in this study is the ramp detection in the output power. To detect the ramp ups and downs, the power variation with time of the proposed sites should be present for the further analysis. So the power variations of given location is as follows:

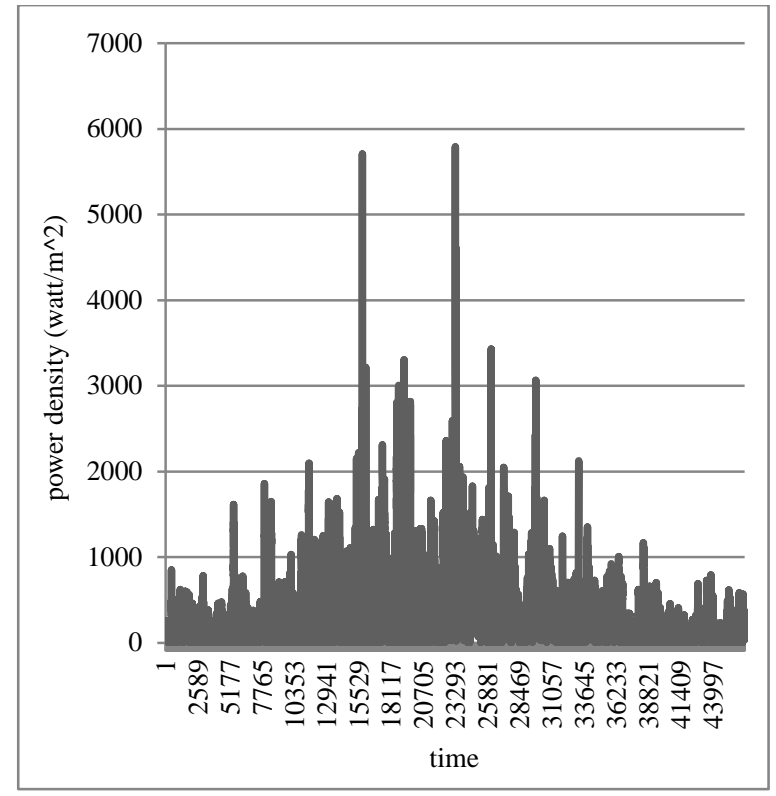

Figure 15:Annual wind power variations with time at Dug site.

Figure 1 shows the annual wind power variations with time at Dug site. These power variations are obtained using wind speed data at 10 minute time interval. Basically Power variations shows that, how much windy the particular field is. These variations changes time to time or we can say season to season. So to analyze the ramping behavior of these wind power variations, the Ramp detection is performed on the actual data collected from NIWE site. A broad data is analyzed in this paper, in which the site has approximately 52540 samples each, over a year. To represent the ramp ups and downs events, analysis is done seasonally. In the present analysis three seasons' winter, 
summer and spring are presented with ramp events using Matlab.

Table 1 :Comparative analysis of Ramp ups/downs at threshold

\begin{tabular}{|c|c|c|c|}
\hline Seasons & $\begin{array}{c}\text { Ramp } \\
\text { ups }\end{array}$ & $\begin{array}{l}\text { Ramp } \\
\text { downs }\end{array}$ & $\begin{array}{c}\text { Total } \\
\text { Ramps }\end{array}$ \\
\hline $\begin{array}{l}\text { Winter } \\
\text { season }\end{array}$ & 480 & 457 & 937 \\
\hline $\begin{array}{c}\text { Summer } \\
\text { season }\end{array}$ & 617 & 654 & 1271 \\
\hline $\begin{array}{l}\text { Spring } \\
\text { season }\end{array}$ & 610 & 597 & 1207 \\
\hline
\end{tabular}

Table 2 :Comparative analysis of Ramp ups/downs at threshold

\begin{tabular}{|c|c|c|c|}
\multicolumn{5}{c}{ power $\left(\mathrm{P}_{\text {th }}\right)=40.5$. } \\
\hline Seasons & Ramp ups & $\begin{array}{c}\text { Ramp } \\
\text { downs }\end{array}$ & $\begin{array}{c}\text { Total } \\
\text { Ramps }\end{array}$ \\
\hline Winter season & 376 & 372 & 748 \\
\hline $\begin{array}{c}\text { Summer } \\
\text { season }\end{array}$ & 579 & 606 & 1185 \\
\hline Spring season & 572 & 541 & 1113 \\
\hline
\end{tabular}

Table 3 : Comparative analysis of Ramp ups/downs at threshold power $\left(\mathrm{P}_{\mathrm{th}}\right)=50.5$.

\begin{tabular}{|c|c|c|c|}
\hline Seasons & Ramp ups & $\begin{array}{c}\text { Ramp } \\
\text { downs }\end{array}$ & Total Ramps \\
\hline $\begin{array}{c}\text { Winter } \\
\text { season }\end{array}$ & 423 & 417 & 840 \\
\hline $\begin{array}{c}\text { Summer } \\
\text { season }\end{array}$ & 596 & 626 & 1222 \\
\hline $\begin{array}{c}\text { Spring } \\
\text { season }\end{array}$ & 589 & 568 & 1157 \\
\hline
\end{tabular}

Table 1, 2, 3 represent the ramp ups, ramp downs and total ramps of the three different seasons like:winter, summer and spring at different threshold powers. Ramp ups and downs in the above tables are estimated using the power density of the selected site by the Matlab programming. After calculating these ramp events the deviations between the real output power and generated power can be evaluated. By understanding these variations in power, the severe damages can be avoided at large scale wind farms.

\section{RESUltS AND CONCLUSION}

\subsection{Results}

To utilize the actual wind power more accurately or we can say for a sustainable wind resource assessment, the ramping behavior of a particular site is essential. In this study to harness more wind power at a specific site, seasonal ramp ups and downs compared graphically.

Figure 2, 3, 4 shows the graphical overview of the ramping nature of proposed site. In which the minimum ramp ups and ramp downs are counted in winter season that is 376 and 372 respectively on 50.5 threshold power. $\square$ Winter season $\quad \square$ Summer season $\quad \square$ Spring season

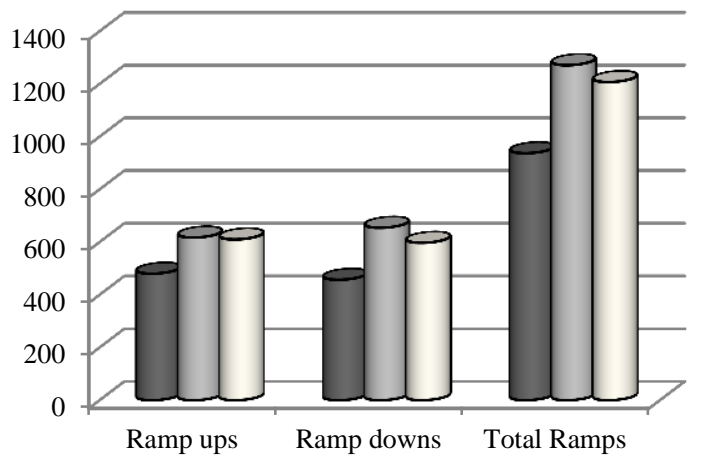

Figure 16: Graphical overview of Seasonal ramping behavior at threshold power $\left(\mathrm{P}_{\mathrm{th}}\right)=30.5$.

घ Winter season $\quad \square$ Summer season $\quad \square$ Spring season

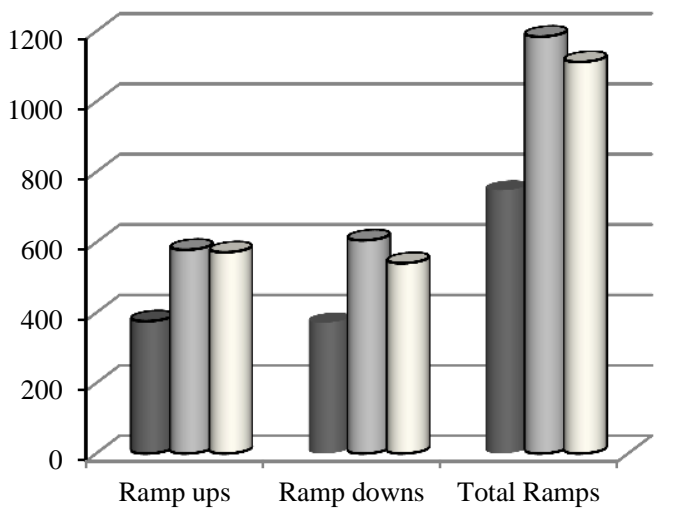

Figure 17: Graphical overview of Seasonal ramping behavior at threshold power $\left(\mathrm{P}_{\mathrm{th}}\right)=40.5$.

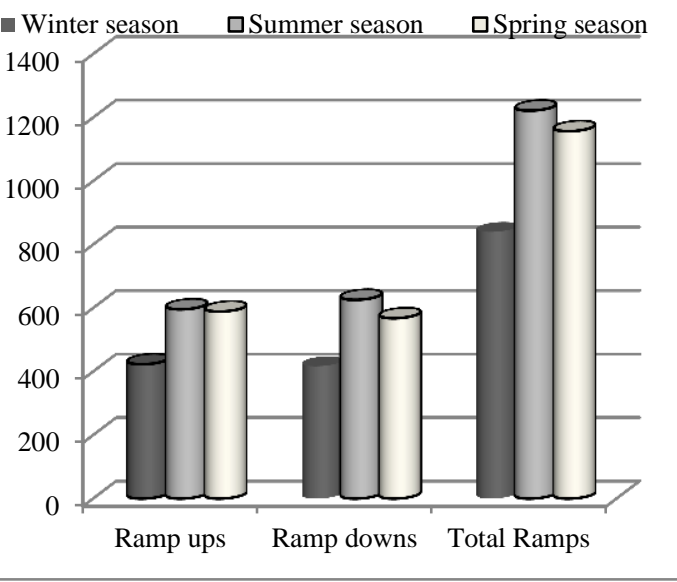

Figure 18: Graphical overview of Seasonal ramping behavior at threshold power $\left(\mathrm{P}_{\text {th }}\right)=50.5$.

\subsection{Conclusions}

The knowledge of detecting the ramping nature of these wind resource assessment is very much helpful in grid connected wind mills. Various hazards to the power systems can be avoided by 
using ramp detection technique. So to install a new wind power plant or wind farms ramp events should be of main considerations.

By observing the results, it could be seen that

- Lower the count of ramp up and ramp downshigher the chances of assessment of wind power potential.

- On 50.5 threshold power the winter season wind is more preferable than summer and spring season.

- As the threshold power increases the chances of ramp ups and downs goes decreases.

\section{REFERENCES}

[1] Nayak, Arun Kumar, Kailash Chand Sharma, RohitBhakar, and JyotirmayMathur. "ARIMA based statistical approach to predict wind power ramps." In 2015 IEEE Power \& Energy Society General Meeting, pp. 1-5. IEEE, 2015.

[2] Pinson, P. "the SafeWind Consortium: Defining a catalogue of complex to extreme events." In Proceedings of the European Wind Energy Conference, Warsaw (PL), pp. 20-23. 2010.

[3] Parsons, Brian, Michael Milligan, Bob Zavadil, Daniel Brooks, Brendan Kirby, Ken Dragoon, and Jim Caldwell. "Grid impacts of wind power: A summary of recent studies in the United States." Wind Energy: An International Journal for Progress and Applications in Wind Power Conversion Technology 7, no. 2 (2004): 87-108.

[4] Kamath, Chandrika. "Understanding wind ramp events through analysis of historical data." In IEEE PES T\&D 2010, pp. 1-6. IEEE, 2010.

[5] Ferreira, Carlos, Joao Gama, L. Matias, AudunBotterud, and J. Wang. A survey on wind power ramp forecasting. No. ANL/DIS-10-13. Argonne National Lab.(ANL), Argonne, IL (United States), 2011.

[6] Sevlian, Raffi, and Ram Rajagopal. "Wind power ramps: Detection and statistics." In 2012 IEEE Power and Energy Society General Meeting, pp. 1-8. IEEE, 2012.

[7] Gallego-Castillo, Cristobal, Alvaro Cuerva-Tejero, and Oscar Lopez-Garcia. "A review on the recent history of wind power ramp forecasting." Renewable and Sustainable Energy Reviews 52 (2015): 1148-1157.

[8] Wan, Y. H. Analysis of wind power ramping behavior in ERCOT. No. NREL/TP-5500-49218. National Renewable Energy Lab.(NREL), Golden, CO (United States), 2011

[9] National Institute of Wind Energy, Wind Data. http://niwe.res.in:8080/NIWE_WRA_DATA/ 